\title{
Archeaological Testing of Site 41VV801 Val Verde County, Texas
}

\author{
A. Joachim McGraw
}

Follow this and additional works at: https://scholarworks.sfasu.edu/ita

Part of the American Material Culture Commons, Archaeological Anthropology Commons, Environmental Studies Commons, Other American Studies Commons, Other Arts and Humanities Commons, Other History of Art, Architecture, and Archaeology Commons, and the United States History Commons

Tell us how this article helped you.

This Article is brought to you for free and open access by the Center for Regional Heritage Research at SFA ScholarWorks. It has been accepted for inclusion in Index of Texas Archaeology: Open Access Gray Literature from the Lone Star State by an authorized editor of SFA ScholarWorks. For more information, please contact cdsscholarworks@sfasu.edu. 


\section{Archeaological Testing of Site 41VV801 Val Verde County, Texas}

\section{Licensing Statement}

This is a work produced for the Texas Department of Transportation (TxDOT) by the report producer. TxDOT and the report producer jointly own all rights, title, and interest in and to all intellectual property developed under TXDOT's contract with the report producer. The report may be cited and brief passages from this publication may be reproduced without permission provided that credit is given to both TxDOT and the report producer. Permission to reprint an entire chapter, section, figures or tables must be obtained in advance from either the Supervisor of the Archeological Studies Branch, Environmental Affairs Division, Texas Department of Transportation, 125 East 11th Street, Austin, Texas, 78701 or from the report producer. 
ARCHAEOLOGICAL TESTING OF SITE $41 \mathrm{VV} 801$

VAL VERDE COUNTY, TEXAS

B y

A. Joachim McGraw 


\begin{abstract}
During March of 1986, archaeologists from the cultural resources staff of the State Department of Highways and Public Transportation (SDHPT) conducted limited testing at the prehistoric site of 41VV801 in eastern Val Verde County, Texas. Portions of the site, which is located along a terrace remnant between Miers Draw and Red Bluff Creek, extend into the right-of-way of US Highway 277. The area within the right-of-way was investigated to determine the site's significance and its merit as a State Archeological Landmark. The results of testing indicated that the site had been disturbed extensively by a long span of natural processes, the most significant of which was determined to be hydrological scouring from nearby drainages. Little evidence remained of stratified cultural deposits and the material collection from excavated units was considered minimal. On the basis of subsurface examinations and analysis of recovered materials, 41VV801 is not considered worthy of State Archeological Landmark designation. Less than $10 \%$ of the estimated former site area is thought to remain relatively intact, given the past impacts of earlier highway and bridge construction, land clearing, and natural erosional processes.
\end{abstract}




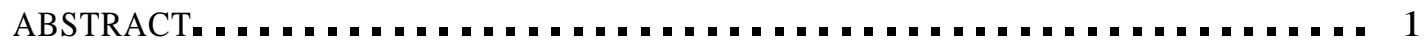

LIST OF FIGURES............................. 3

LIST OF TABLES ........................... 4

I NTROD U CTION ................. 5

ENVIRONMENTAL BACKGROUND....................... 9

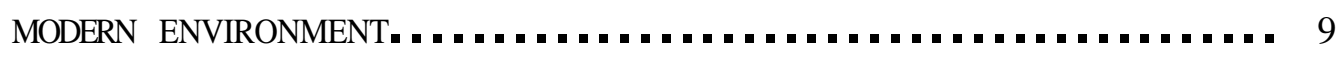

POST-PLEISTOCENE ENVIRONMENTAL SUMMARY ............................... 14

ARCHAEOLOGICAL BACKGROUND ................................ 17

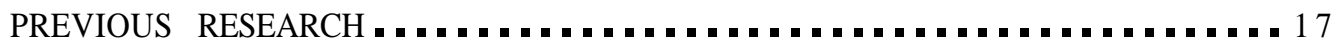

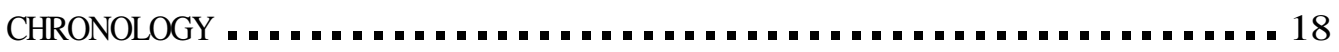

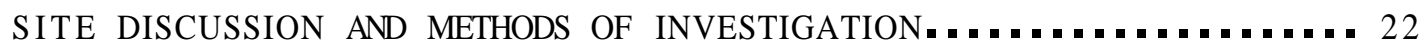

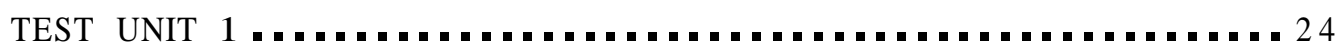

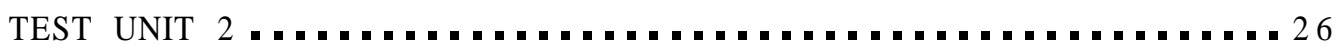

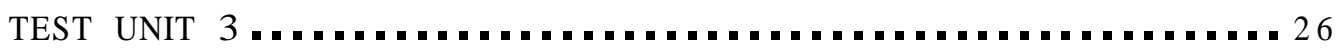

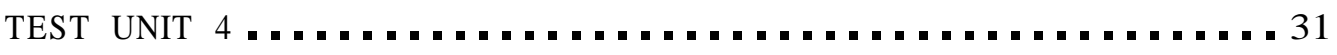

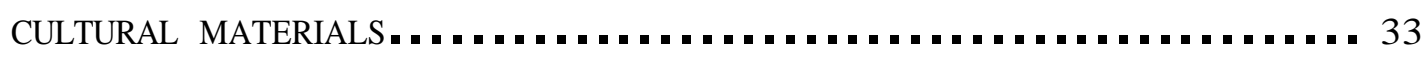

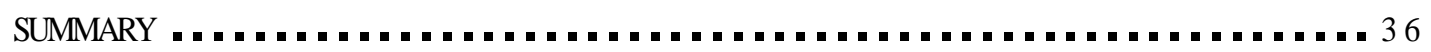

RECOMMENDATIONS .......................................... 40

REFERENCES CITED ........................................... 4 


\section{LIST OF FIGURES}

FIGURE 1. General location of Site 41VV801 i n Val Verde County,

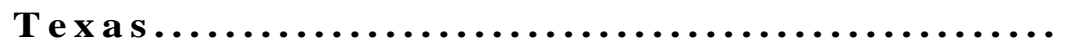

FIGURE 2. Topography and physiography in the vicinity of 41VV801.. 11

FIGURE 3. The environment of Site $41 \mathrm{~V} 801 \ldots \ldots \ldots \ldots$

FIGURE 4. Site 41VV801 showing the location of test units and profile of topography.................... 23

FIGURE 5. Profiles of north walls, Test Units 1, 2, 3, and 4, 41VV801

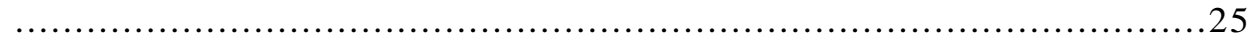

FIGURE 6. Collected artifacts from Site $41 \mathrm{~V} \vee 801 \ldots \ldots \ldots \ldots \ldots . . . .29$

FIGURE 7. Composite stratigraphic profile at Site 41VV801........ 37 


\section{LIST OF TABLES}

TABLE 1. Post-Pleistocene environmental reconstruction..........16

TABLE 2. Summary of chronological sequence derived for the Lower Pecos ................................................

TABLE 3. Provenience of collected materials .................27 


\section{INTRODUCTION}

Negative evidence from an archaeological site often can make a useful contribution toward a better understanding of prehistory as well as offering insights into modern aspects of the natural environment. A lack of cultural materials or their loss through time by natural processes may reflect significant environmental influences that have shaped the pattern of material evidence that is recognized today. The prehistoric occupation site of $41 \mathrm{VV} 801$ is thought to represent such a locale.

Located in eastern Val Verde County approximately 36 miles $(59 \mathrm{~km})$ north of Del Rio (Fig. 1), 41VV801 was first identified in October of 1985 by Daymond D. Crawford of the State Department of Highways and Public Transportation (SDHPT) cultural resources staff. Situated near the confluence of two intermittent drainages, the site is just north of Red Bluff Creek and west of Miers Draw. A portion of the archaeological site extends into the SDHPT right-of-way along US Highway 277 just north of the highway bridge over Red Bluff Creek.

This report presents the results of limited testing of this area following proposed bridge modifications that would impact a segment of 41VV801 known to exist adjacent to US H ighway 277. The site was investigated in March of 1986 by Wayne C. Young and A. Joachim McGraw of the SDHPT cultural resources staff. Field support was provided by the SDHPT District 7 maintenance staff from Sonora, Texas. A total of 16 persondays was utilized during the testing period and a total of approximately 9 cubic meters of soil was excavated from four separate 1-meter-square test units. These were distributed across a 30-by-130-meter length of 
This Page Redacted Per THC Policy 
highway right-of-way. A 11 work was performed in accordance with Procedures for the Protection of Historic and Cultural Properties (36 CFR, Part 800), procedures prescribed and endorsed by the Federal Highway Administration, and also followed the guidelines presented in the Council of Texas Archeologists' professional performance standards (Council of Texas Archeologists 1985). The site investigations were directed toward an objective determination of the location's potential for nomination as a State Archeological Landmark. Assessments of site potential were based upon the horizontal and vertical extent of cultural materials, significance of cultural deposits, and an interpretation of site integrity in the light of modern alterations and natural impacts.

The results of field work indicated that the integrity of material deposits had been severely damaged by both long-term natural processes as well as previous highway construction and land clearing. These latter effects have disturbed upper subsurface deposits to a depth of 12 $\mathrm{cm}$ or more. Lower deposits have been eroded by high-energy flooding episodes that have scoured normal soil deposits and have interbedded an extensive layer of calcareous gravels, pebbles, and cobbles in their place. This gravel/pebble/cobble layer was identified ca. $30 \mathrm{~cm}$ below the surface and graded into much larger, heavier stream-rolled cobbles and stones. A compacted silty clay layer ca. $10 \mathrm{~cm}$ below the surface and 9 to $12 \mathrm{~cm}$ thick represented the least disturbed soil zone across the site area and was tentatively associated with a light, marginal scatter of lithic debris distributed throughout the test units (see the Site Discussion and Methods of Investigation section for a more detailed 
discussion). A description of the background, investigations, and interpretations of 41VV801 is presented in the following sections. 
ENVIRONMENTAL BACKGROUND

Modern Environment

Val Verde County, an irregularly shaped area of 3259 square miles, is located in an environmental transition zone that includes the margins of two separate natural regions of Texas. Known physiographically as the Lower Pecos, or Pecos Lowlands (Johnson 1931:53), the zone is characterized by a deeply dissected topography. Physically, it separates the southwestern margins of the Edwards Plateau from the eroded limestone uplands of the Stockton Plateau and is considered to be an extension of the Comanchean Cretaceous limestones of the Edwards Plateau (Johnson 1931:105).

The southeastern portion of the county is associated with the Rio Grande Plain (Golden et a1. 1982:1). Altitude above mean sea level (msl) varies from ca. $2350 \mathrm{ft}$. in the northern section of the county to $900 \mathrm{ft}$. in the south. Three major rivers and a number of their associated tributaries drain the area: the Rio Grande, Pecos, and Devil's Rivers. In modern times, Amistad Lake, one of the largest reservoirs in Texas, supplements the available surface water resources of the county.

Because of its distinctive physiography, Val Verde County is also considered to be part of two distinct biotic provinces of the state (Blair 1950:105). The Balconian Province, roughly comparable to the natural region of the Edwards Plateau, extends into the eastern portion of Val Verde County toward the Pecos River drainage. The area lying west of 
this river reflects elements of the Chihuahuan Biotic Province. While both of these regions represent distinctive ecological areas, it should be noted that these environmental systems reflect a complex mixture of inter-regional flora and fauna as well as the greatest diversity of physiographic features of any of the biotic provinces in Texas (Blair 1950:105). In the most pragmatic perspective, the broad descriptions that identify this transition zone do not reflect the complexity of the physical elements of the general study area. From an archaeological perspective, the diversity of this environmental transition zone is further magnified by a long span of prehistoric subsistence patterns that lie superimposed across the natural resources of this landscape (Figs. 2 and 3 ).

The fauna of this arid region includes most of the 57 species of mammals from the Balconian Province as well as additional animals characteristic of the Mexican tableland and the southwestern deserts (Blair 1950:107113). Mammals related to the Chihuahuan Biotic Province include ringtail (Bassariscus astutus), pallid bat (Antrozous pallidis), hog-nosed skunk (Canepatus mesoleucus), botta pocket gopher (Thomomys bottae), brush mouse (Peromyscus boylii), and others (Davis 1960). Larger fauna commonly includes white-tailed deer (Odocoileus virginianus), collared peccary (Pecari tajacu), and occasionally several members of the cat family: cougar (Felis concolor), ocelot (Felis pardalis), and bobcat (Lynx rufus). The study area is also estimated to contain approximately 16 species of lizards and 36 species of snakes. Two species of ribbon snake, the hooknose snake, and the northern blacktail rattlesnake are found only in the Balconian/Chihuahuan environments (Blair 1950:113-115). 
This Page Redacted Per THC Policy 


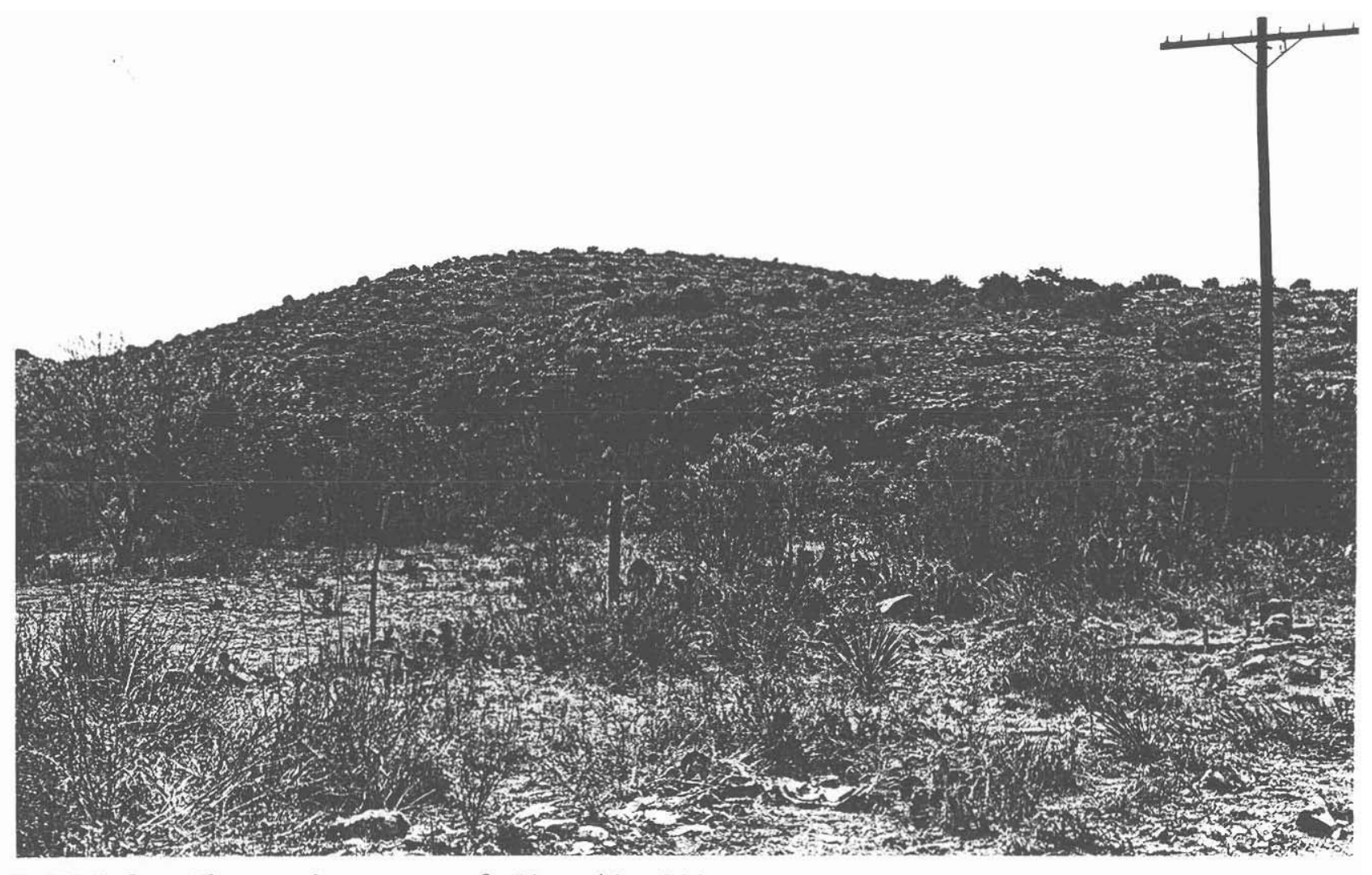

FIGURE 3. The environment of Site $41 \mathrm{VV} 801$. 
Climax flora that dominates the general study area includes the ubiquitous mesquite (Prosopis juliflora) and thorny shrubs such as catclaw huisache, and others. The eastward extension of the Chihuahuan Biotic Province also includes such flora as beargrass (Nolina texana), lechuguilla (Agave lecheguilla), creosote bush (Larrea), catclaw (Acadia greggii), and blackbrush (Flourensia). Occasional stands of Texas oak (Quercus texana) and stunted live oak (Quercus virginiana) can be noted within the riparian zones of drainages. Scrubs of Mexican cedarjuniperus mexicana) may also be observed in this transition zone.

Val Verde County is drained by three major river systems: the Rio Grande, Pecos and Devil's Rivers. The last is most significant to this study as Red Bluff Creek, adjacent to Site $41 \mathrm{VV} 801$ is a major tributary of this river system. Approximately 20 miles in length, the creek channel meanders to a confluence with an eastern fork of the Devil's River, the Dry Devil's River, ca. 12 miles west of $41 \mathrm{VV} 801$.

Red Bluff Creek and its environs are characterized by a sinuous, cobblestrewn floodplain often more than 50 meters wide. The extent and size of the stream-rolled cobbles and stones (some more than $40 \mathrm{~cm}$ in diameter) reflect the energy and velocity of flooding episodes along the intermittent drainage. Large branches of driftwood observed in a small, scoured rockshelter ca. 10 meters above the terrace suggest that past floods have completely inundated the low terrace associated with 41VV801 in the past. This phonomenon would have been characterized by several meters of rapidly moving water creating violent hydrological turbidation. 
Val Verde is considered to have a semi-arid, continental climate. Average temperatures range from $35^{\circ} \mathrm{F}$ in the winter months to an average summer temperature of $98^{\circ} \mathrm{F}$. The lowest temperature on record was noted in 1951 as $11^{\circ} \mathrm{F}$. The highest summer temperature was recorded i n 1960 as $111^{\circ} \mathrm{F}$. Climate summaries by the National Oceanic and Atmospheric Administration, US Department of Commerce, indicate that cold periods may drop temperatures as much as 25 degrees in a few hours and temperatures as high as $100^{\circ} \mathrm{F}$ have been recorded as early as March. The average annual rainfall measured at Del Rio is 18.38 in.; over $60 \%$ of this falls between April and October (Golden et al. 1982:2, 98).

\section{Post-Pleistocene Paleo-Environmental Summary}

The Lower Pecos area at the end of the Pleistocene epoch, ca. 12,000 years ago, is thought to have consisted of a parkland savannah that supported such extinct fauna as camel, horse, and bison. Lundelius (1984) has suggested that uplands throughout the Lower Pecos were covered by grasslands and savannah from 14,000 to 12,000 years ago. Lundelius in part based his interpretations on the identification of such grazing animals as Equus and Bison whose faunal remains have been recovered in this area. Pinon pine dating from 16,000 to 11,000 years B.P. also has been identified in the Lower Pecos, and relic stands still can be found today in neighboring Sutton, Edwards, and Real Counties (Turpin 1985:44).

A summary by Bryant (1966) of postulated climatic changes from the Lake Amistad area just southwest of the study area suggests five chronological stages and three climatic intervals. These data were based on 
faunal remains and recovered pollen from archaeological sites. This information is summarized in Table 1. Patton's (1977) data regarding flood deposits from Arenosa Shelter are compared to Bryant's (1966) work. It should be noted that studies of pollen stratigraphy at the Devil's Mouth Site suggest that climates associated with thin, finegrained flood deposits were more humid than the present climate (Patton and Dibble 1982:109).

For a more detailed review of paleoclimates and environmental data, the reader is referred to Turpin (1984:44-7, 1985:48-52), Patton and Dibble (1982), and the cited references of Sorrow (1968:69-70) and Collins (1974).

In summary, the environmental factors that have shaped the modern character of the Lower Pecos reflect a long span of increasing aridity. The natural conditions that affected the pattern of prehistoric hunters and gatherers for millenia represent a marked contrast to the harsh, often extreme, environmental conditions of today. 
TABLE 1. Post-Pleistocene paleo-environmental reconstruction, Lower Pecos area.

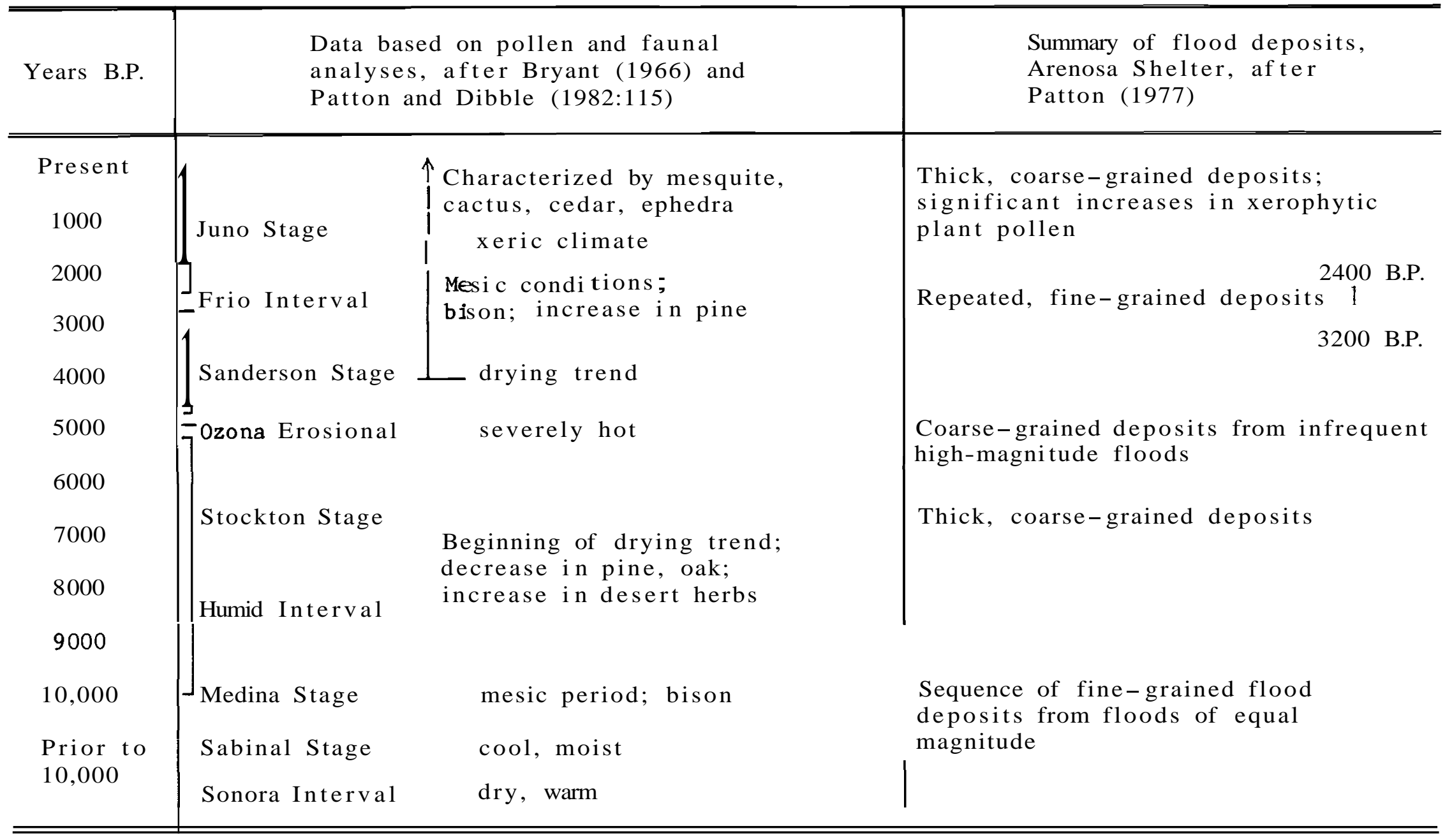


ARCHAEOLOGICAL BACKGROUND

\author{
Previous Research
}

The natural conditions of the Lower Pecos, especially the aridity of the region, have contributed to the preservation of perishable prehistoric remains too often destroyed by natural processes elsewhere. Recovered materials from excavated rockshelters and caves prior to the inundation of Lake Amistad have contributed significantly to the information available for the regional archaeological record (e.g., Centipede and Damp Caves, Devil's Mouth, Bonfire Shelter, Devil's Rockshelter, Arenosa, and others).

Additionally, the identification and study of numerous pictographs in the general study area have resulted in a preliminary typology and chronological sequence of this art form.

Casual interest in the prehistory of the Lower Pecos dates to the late nineteenth century when surveyors first mapped the area (Turpin 1984:7). It was not until the 1930s, however, that formal museum and academically sponsored projects began collecting artifacts from numerous rockshelter sites. Concurrent with this work were the first efforts toward the study of pictographs by Forrest Kirkland and A. T. Jackson.

Almost a decade passed after these significant pioneering efforts; and it was not until the development of Lake Amistad in the 1950s that further systematic, salvage-oriented, research took place. Intensive surveys, limited testing, and excavations of shelters as well as 
documentation of pictographs characterized these research efforts. Two results of this work were the establishment of a prehistoric chronological sequence and a recognition of the stylistic changes of the area's art style.

Since the 1970s, climatic and ecological studies (e.g., Dering 1979; Turpin 1985; and others) have integrated paleo-environmental data toward a more refined view of hunter-gatherer subsistence patterns. Further work in the Lower Pecos will contribute to a body of information that is both unique in its material context as well as its state of preservation. As such, the area's material cultural remains offer insights into the regional prehistory as well as toward interregional comparisons.

\section{Chronology}

The prehistoric chronological sequence derived from past studies of the Lower Pecos represents a long span of aboriginal exploitations that covers four major cultural time frames: the Paleo-Indian, Archaic, Late Prehistoric, and Historic Indian Periods. The earliest evidence of human occupation comes from 41VV218, Bonfire Shelter, where extinct bison bones have been associated with Paleo-Indian Folsom and Plainview projectile points (see also Dibble and Lorrain 1968 and Bement 1986). Another Val Verde site, 41VV162, also has some evidence of human activity 12,000 to 14,000 years ago (Hester 1980:132). Late PaleoIndian diagnostic lithic indicators in the area also include Golondrina and Angostura projectile points. Turpin (1984:14) has observed that the remains of many Paleo-Indian activities may have long been 
destroyed by natural changes and other factors. The modern identification of such remains may be due more to the vagaries of favorable preservation rather than a reflection of occupational intensities.

The predominant archaeological remains in the study area consist of sites and artifacts associated with Archaic lifeways. In the most general terms, this period is distinguished from the earlier PaleoIndian time frame by progressive but broadly stable adaptations to slowly changing environmental conditions. The Archaic Period of the Lower Pecos (ca. 6000 B.C. to A.D. 900 or 1000) is recognized as a long span of hunters and gatherers of chronologically and probably culturally distinct bands or groups. The remains of this time are reflected in the aboriginal record by pictographs, cemetery or burial sites, and a large number of open campsites and dry shelters.

Early Archaic sites (ca. 6500 to 4000 B.C.), as in other adjacent areas i n Texas, often contain a series of distinctive corner-notched projectile points similar to those identified as Bell, Martindale, Uvalde, or other poorly defined Early Corner-Notched varieties of central and southern Texas. Middle Archaic (ca. 4000 to 1000 B.C.) chronological index markers include projectile points similar to Nolan, as well as Pandale, Langtry, Almagre, and Val Verde. Commonly recognized projectile points associated with the Late Archaic Period (ca. 1000 B.C. to A.D. 900) include dart points similar to those found in central Texas such as Montell, Castroville, Marshall, Marcos, and Shumla. Stratigraphically overlying these types are such projectile points as Ensor, Frio, Fairland, Paisano, and Figueroa. Late Prehistoric (ca. A.D. 900 
to European contact) arrowpoints include Cliffton, Perdiz, Scallorn, Toyah, and Livermore. Index markers to later Historic Indian sites are often metal arrowpoints.

Story and Bryant (1966) have derived an archaeological chronological sequence for the Lower Pecos that identifies eight (local) periods ranging from ca. 11,000 B.P. to the Historic Indian Period. This sequence may be compared to Collins (1974) nine chronological episodes for Arenosa Shelter. By far, the most complex chronology to date is Dibble's (n.d.) twelve-phase construct that ranges from a poorly defined Aurora Phase (before 12,000 B.P.) to the Historic Indian Phase (ca. 250 B.P.). The postulated sequences of Story and Bryant (1966), Collins (1974), and Dibble (n.d.) are summarized in Table 2 which, because of its usefulness, is extracted from Turpin (1985:7).

In summary, this brief overview can identify only the broadest elements of a complex and enduring pattern of aboriginal lifeways. While past researchers have glimpsed a shadow of these former peoples through their material remains, future research still must contend with the more basic problems of typology, a poorly described chronology, and the slowly disappearing evidences of past cultures. 
TABLE 2. Summary of chronological sequences derived for the Lower Pecos, extracted from Turpin (1985:7).

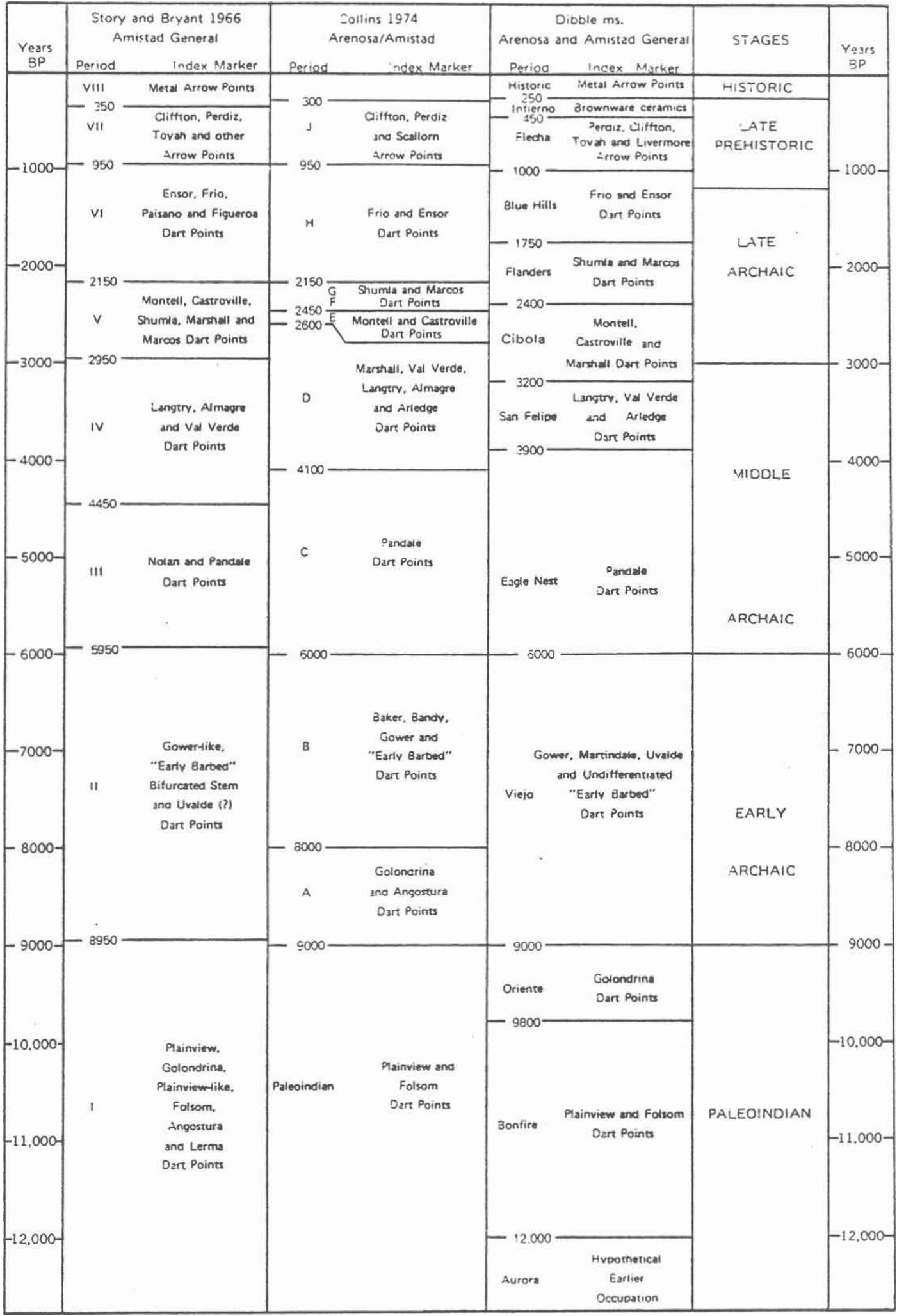




\section{SITE DISCUSSION AND MEIHODS OF INVESTIGATION}

Site investigations were directed toward the identification and assessment of prehistoric cultural materials in the highway right-of-way and adjacent to the bridge structure across Red Bluff Creek. No new rightof-way was involved in the proposed construction.

Site 41VV801 was tested by four 1-meter squares excavated to a depth of $80 \mathrm{~cm}$ below the surface (100.00 to 99.20 meters arbitrary elevation) along a narrow right-of-way that sloped toward Red Bluff Creek (Fig. 4). Total volume of excavated material is estimated at 9 cubic meters of soil over an identified site area of ca. 30 by 130 meters along the northeastern right-of-way segment of US Highway 277. It should be noted that only a portion of this 130-meter length (about 30 to 40 meters) is to be affected by bridge construction. A total of 16 person-days was expended during the field work which employed hand rather than mechani cal excavation methods. Test Units 3 and 4 , north of the construction area, were investigated as control test units to be compared with deposits from Test Units 1 and 2 , as well as to establish a broader sample of site materials.

All units were excavated utilizing trowels and other small hand tools. A permanent, arbitrary datum point was established along the fence line at the edge of the east right-of-way at highway station 1504. This point was designated 100.00 meters as a vertical datum and was utilized to correlate all subsurface measurements between test units. Following intensive survey, the total original prehistoric activity area is estimated to have been 150 meters or more in diameter. Within the highway right-of-way, the effects of natural erosion as well as modern 


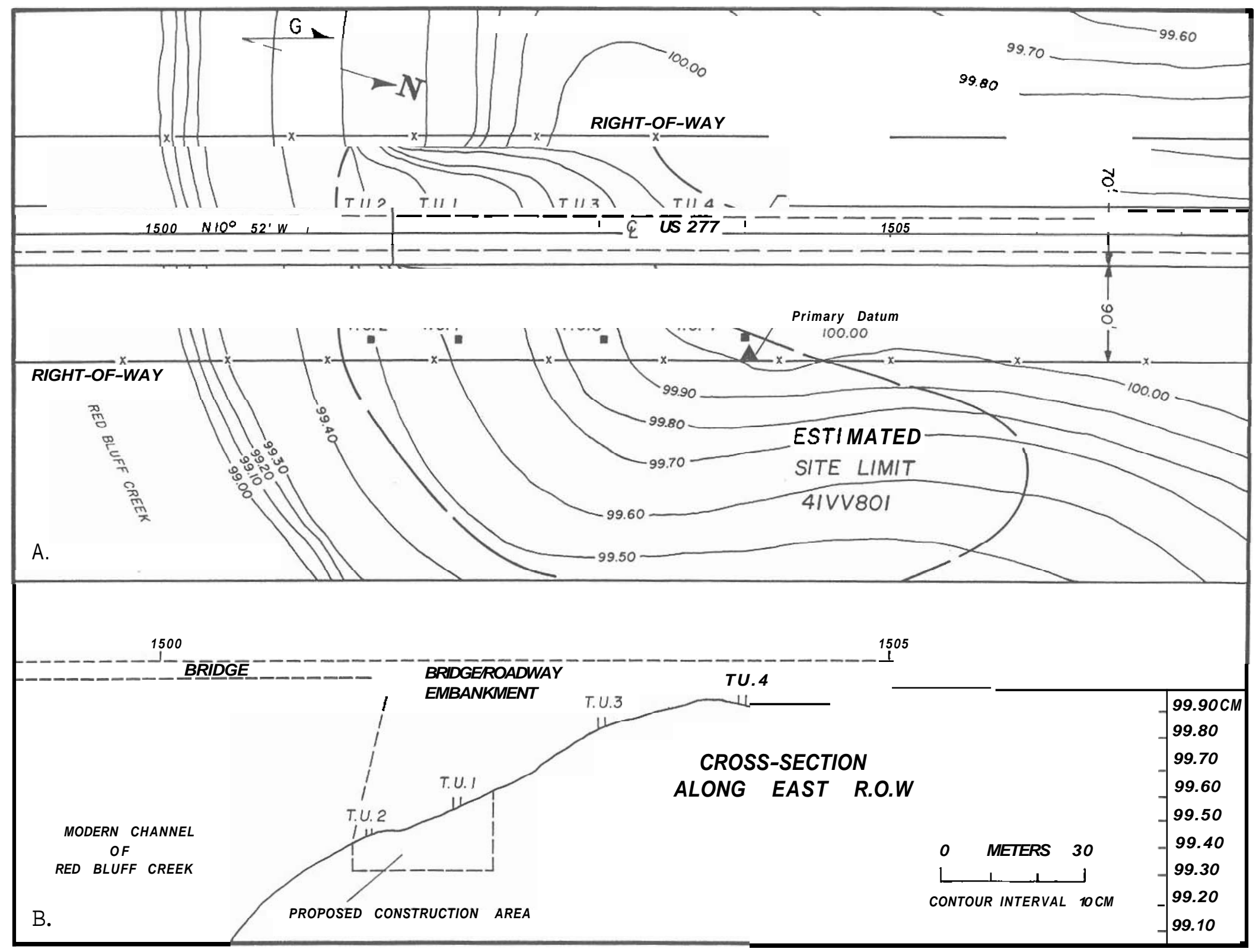

FIGURE 4. Site 41VV801 showing location of test units and profile of topography. 
highway and bridge construction have destroyed all but a remnant of this original occupation area that was examined during testing. All collected materials were processed and analyzed at the Archaeology Laboratory of the SDHPT, Austin.

Given the limited and narrow highway right-of-way in this location, a simple consistent-interval sampling methodology was utilized, with units spaced at 100-ft. (ca. 33-meter) intervals adjacent to established highway station markers. These locations offered permanent reference points in defining the horizontal relationships of tested units. A summary of individual test unit investigations is presented below.

\section{Test Unit 1}

Test Unit 1, a 1-meter square, was excavated from 99.62 to 99.02 meters (Fig. 5). This test unit was located adjacent to highway station marker 1502. The upper $10 \mathrm{~cm}$ of this unit consisted of a silty, fine-grained, unconsolidated upper soil zone. This zone is related to elements of the Olmos deposit--very gravelly loam, a moderately alkaline brown soil that occurs on old outwash deposits on uplands (Golden et al. 1982:75). From 10 to $30 \mathrm{~cm}$ below the surface, the matrix became much more calcareous and compacted with small gravel and pebble intrusions.

Over $70 \%$ of the light scatter of lithic debris collected from Test Unit 1 was recovered in the first $20 \mathrm{~cm}$ of soil deposits. Below a level of $30 \mathrm{~cm}$, gravel pebbles and cobbles dominated the soil composition. By 50 cm below the surface, an almost solid floor of calcareous cobbles and stones (some up to $20 \mathrm{~cm}$ in diameter) was exposed, and these materials almost completely displaced lower soil zones. 


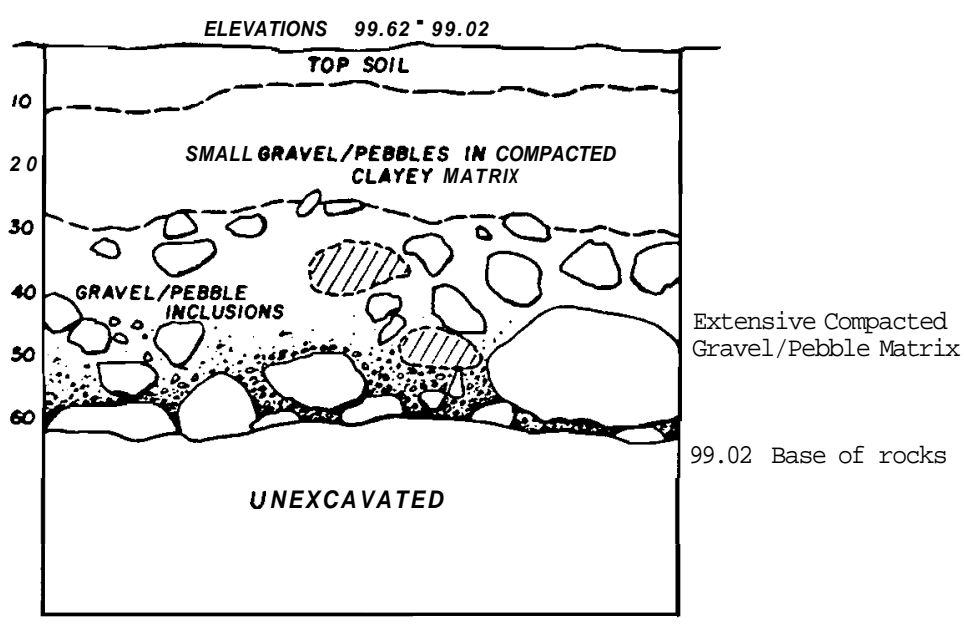

TEST UNIT I

ELEVATIONS 98.85

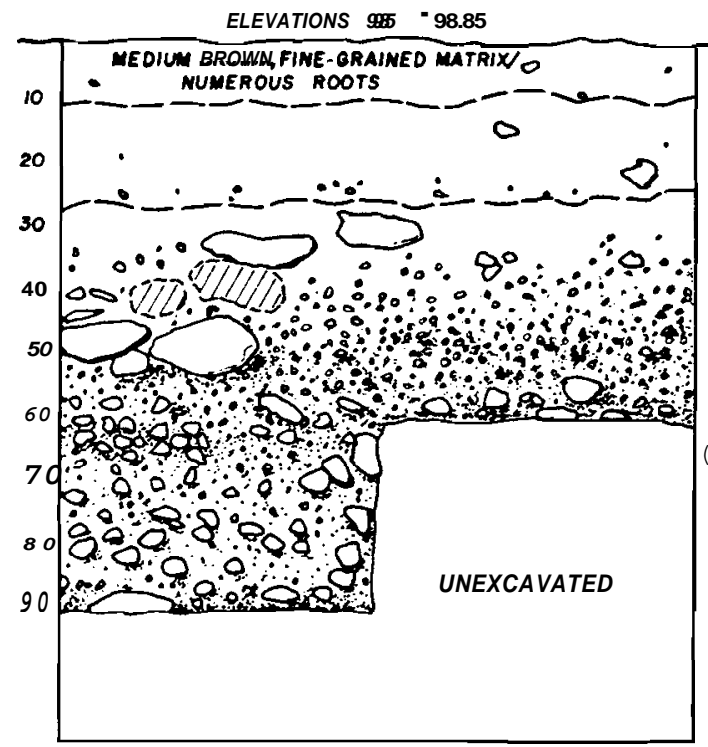

TEST UNIT 3
Unconsolidated. Silty Top Soils

Slightly More Compacted Soils/ Less Roots

Beginningof Small Gravel/Pebbles

Light Grayish Brown Soils

To Bottom of Unit)

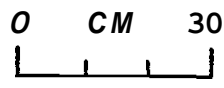

EXTRACTED COBBLES
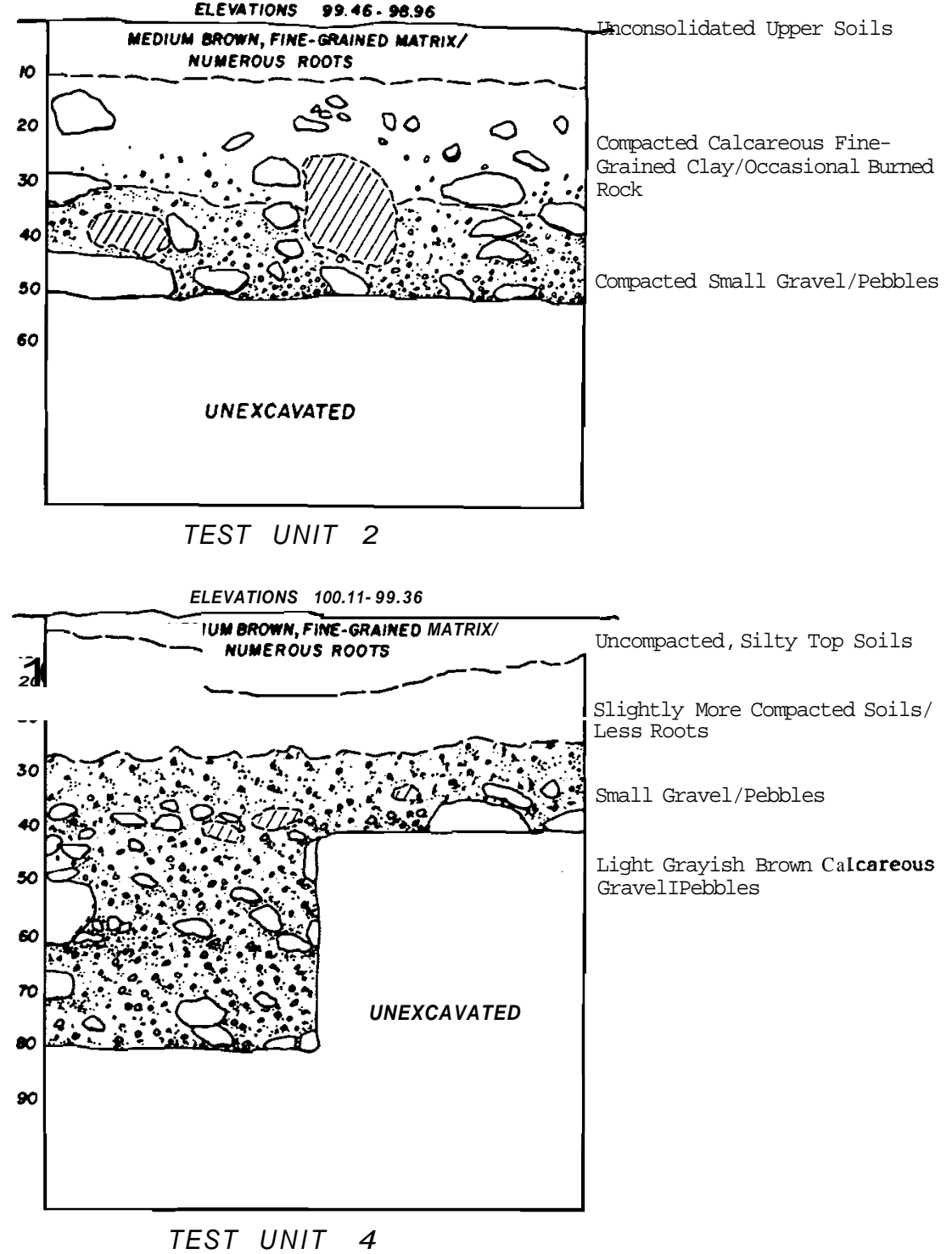

FIGURE 5. Profiles of north wall, Test Units 1, 2, 3, 4, Site 41VV801. 
No cultural features or diagnostic materials were noted or collected from this test unit. A total of 15 fragments of lithic debris was recovered from $40 \mathrm{~cm}$ of deposits, and 9 of these reflected some evidence of use wear and/or marginal retouch (see Table 3 ).

\section{Test Unit 2}

Test Unit 2, a 1-meter square, was excavated from 99.46 to 98.96 meters (Fig. 5). Located 14 meters south of Test Unit 1, this second test unit was placed along the edge of the low terrace and the margins of the modern creek channel. Natural deposits were similar in composition to those of Unit 1 and, again, large calcareous cobbles and small boulders were uncovered ca. $50 \mathrm{~cm}$ below the surface. A total of 16 fragments of lithic debris was collected at $10 \mathrm{~cm}$ intervals; these were evenly divided between upper and lower levels and separated by a sterile level $3(20$ to $30 \mathrm{~cm}$ below the surface; 99.26 to 99.16 meters elevation). Of the specimens recovered, 14 reflect unpatterned edge damage in the form of nicking; this nicking may have been caused by stream rolling and/or battering. A small subtriagular uniface, $6 \mathrm{~cm}$ in length (Fig. 6), was collected from Level $1(0$ to $10 \mathrm{~cm} ; 99.46$ to 99.36 meters elevation. Manufactured from a fine-grained, medium-gray chert, the artifact is characterized by multiple-angled working edges and ends. No other diagnostic artifact or features were noted in this unit.

\section{Test Unit 3}

Test Unit 3, a 1-meter square, was excavated from 99.85 to 98.95 meters (Fig. 5). Located adjacent to highway station marker 1503, Test Unit 3 was excavated to a depth of $90 \mathrm{~cm}$. Although this location (like Test 
TABLE 3. Provenience of collected materials from $41 \mathrm{VV} 801$.

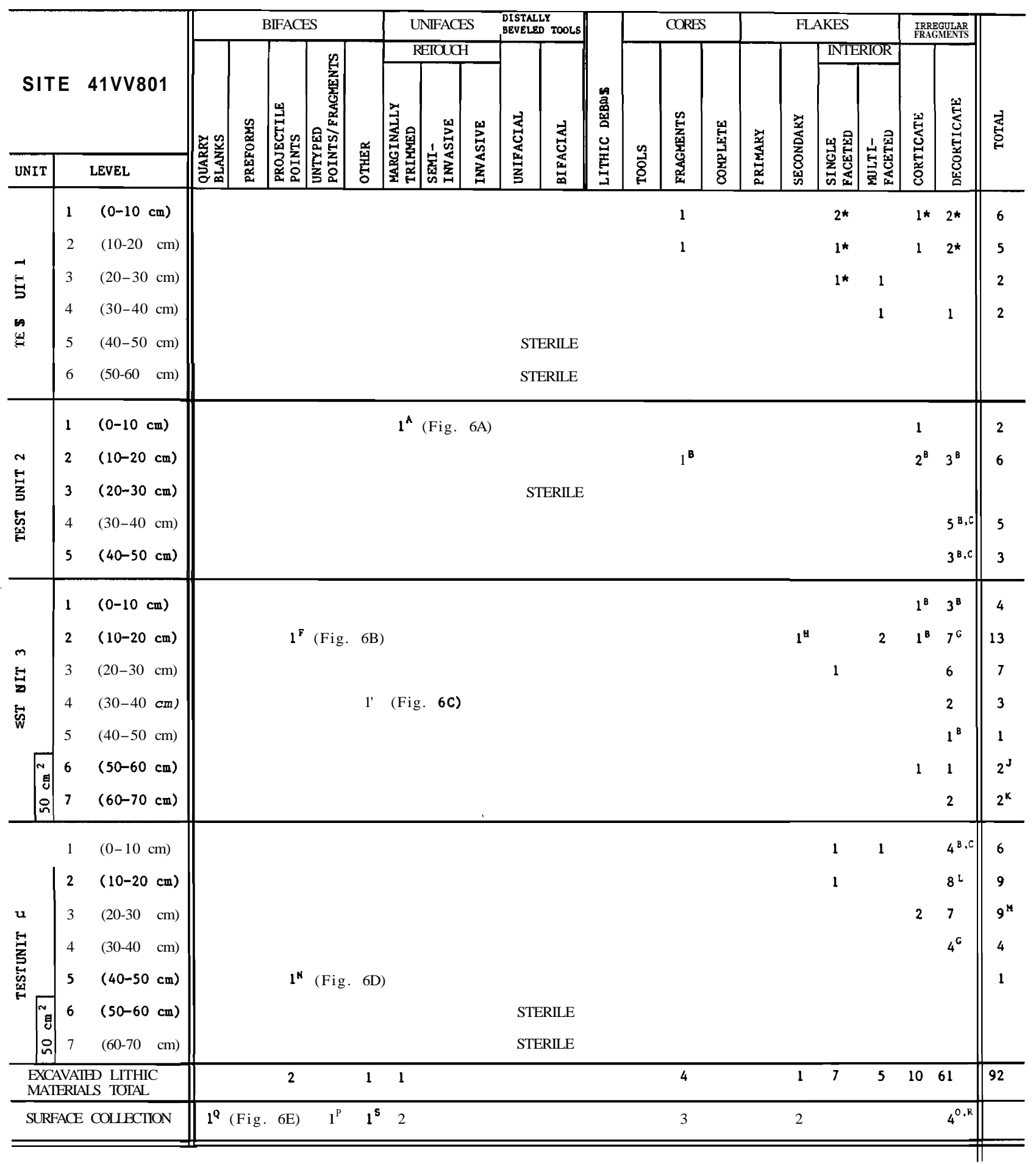


Notes to Table 3.

"Indicates use/wear or marginal retouch

$\mathbf{A}=$ Interior flake, marginally trimmed along dorsal edges

$B=$ Edge damage (nicking, etc.) may be due to stream rolling

$\mathrm{C}=1$ specimen, a decorticate chip, is burned

$\mathrm{E}=$ Extensive level of stream-rolled gravels

$F=$ Perdiz

$\mathrm{G}=\mathbf{2}$ specimens reflect use-wear edge damage

$\mathrm{H}=$ Possible notching

$\mathbf{I}=$ Marginally trimmed

$\mathbf{J}=$ Specimens extensively patinated

$\mathrm{K}=1$ specimen burned

$\mathrm{L}=3$ specimens burned; 1 steep semi-invasive edge bevel

$M=4$ specimens burned

$\mathrm{N}=$ Corner - notched dart point

$\boldsymbol{O}=\mathbf{3}$ specimens with edge use/wear dmage

$P=$ Distal end, alternately beveled

$Q=$ Percussion flaked

$\mathrm{R}=1$ specimen, patinated, steep alternate edge beveling

$\mathrm{S}=$ Marginally trimmed; possible use-wear 

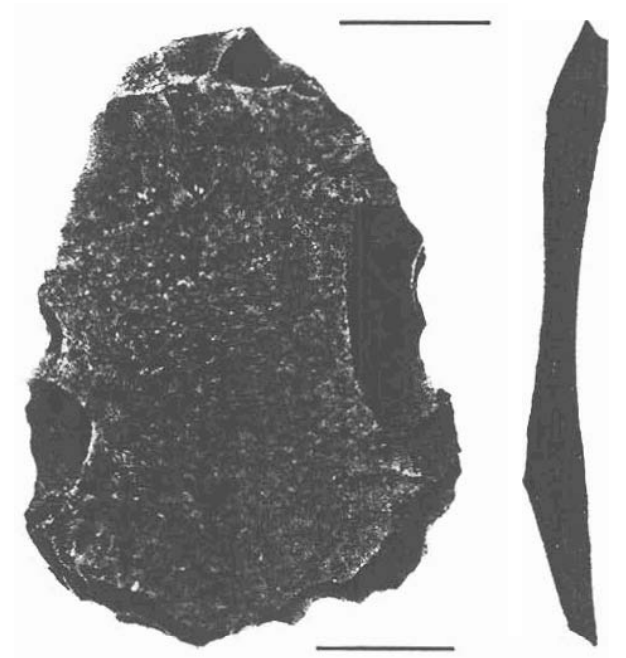

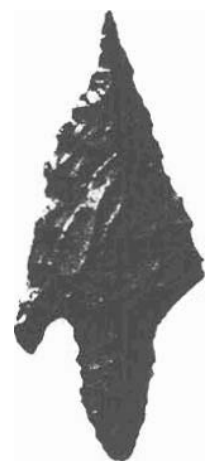

B

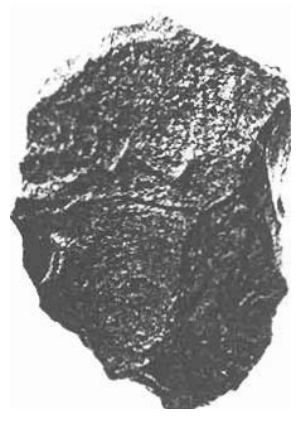

C

A

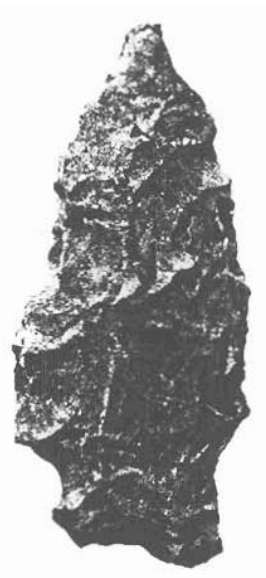

D

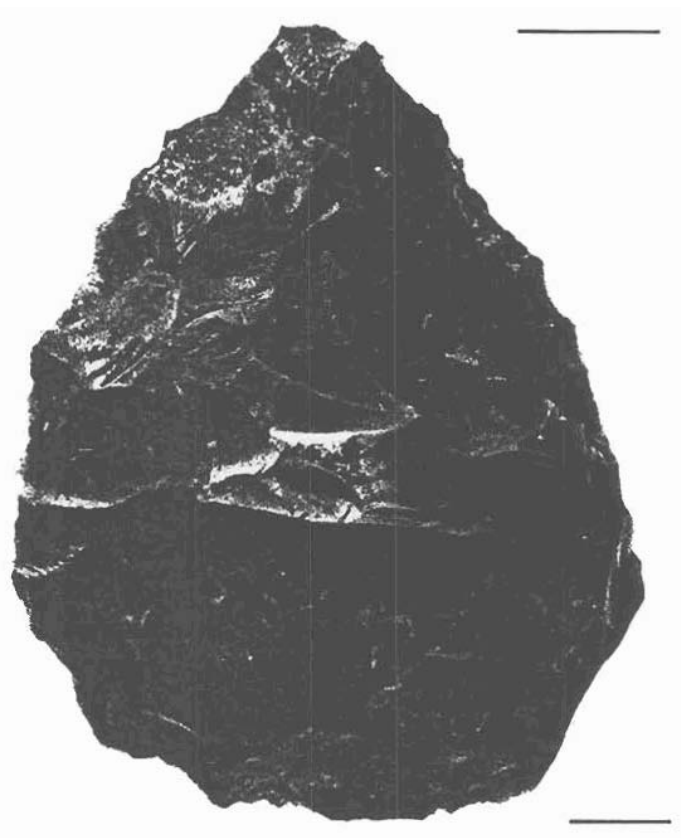

$E$
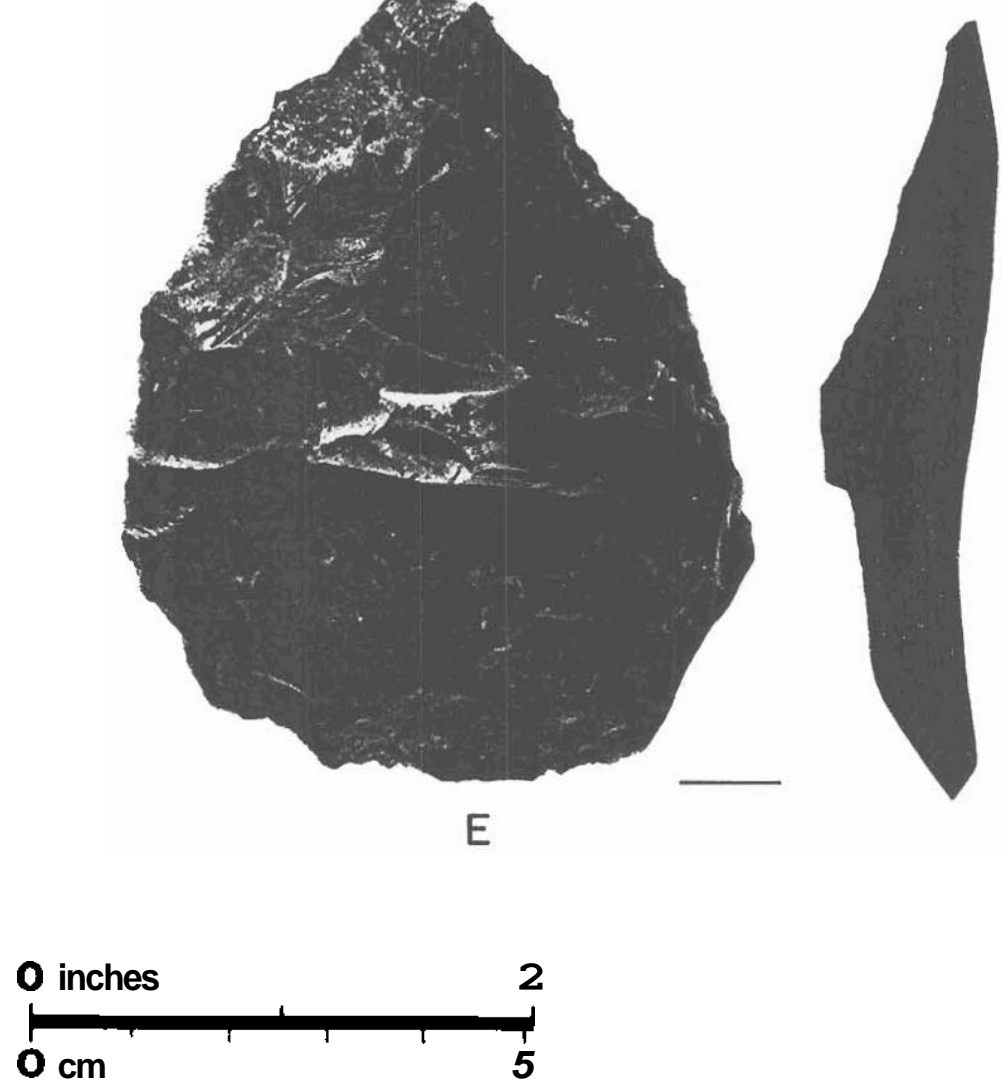

FIGURE 6. Collected artifacts from Site $41 \mathrm{~V}$ V 801 . A, subtriangular uniface, Test Unit 2; B, Perdiz arrowpoint, Test Unit 3; C, marginally trimmed uniface, Test Unit 3; D, extensively reworked projectile point, Test Unit 4; E ovate, marginally trimmed biface, surface collected. 
Unit 4) was not under primary construction impact, it was thought that its proximity to Test Units 1 and 2 as well as its upslope location could define more clearly the extent and density of cultural deposits of 4 1VV801.

Natural deposits of Test Unit 3 consisted of a surface layer of unconsolidated, medium-brown topsoil with numerous root intrusions. Underlying this at 10 to 30 am was a more compacted clayey matrix. A gravel/ pebble composition in the lower levels of the compacted zone gradually increased in both size and density. The middle and lower levels of this unit (99.50 to 98.95 meters) consisted almost entirely of mixed gravels and pebbles. While recognizing the extent of slope involved, this deposit may be contrasted to the large stones and small boulders observed a t approximately the same depths in Test Units 1 and 2.

A total of 32 fragments of lithic debris was collected from this unit as well as a single Perdiz arrowpoint (Fig. 6B) at 99.73 meters (Level 2, ca. 12 an below the surface). A detailed breakdown of lithic debris characteristics is presented in Table 3 . In general, almost $80 \%$ of the lithic materials were recovered in the first three levels. A total of 3 specimens reflect some edge alteration in the form of nicking and notching, and an additional 6 show random edge damage. The degree of patination on both corticate and decorticate chips in Level 6 (50 to $60 \mathrm{~cm}$ below the surface; 99.35 to 99.25 meters) suggests a chronologically earlier activity sequence that predates the overlying Perdizassociated occupation(s). No features or other diagnostic artifacts were noted or collected in Test Unit 3. 


\section{Test Unit 4}

Test Unit 4, a 1-meter square, was excavated from 100.11 to 99.36 meters (Fig. 5). Test Unit 4 was located 4 meters south of highway station marker 1504 and ca. 33 meters north of Test Unit 3. Four soil and subsoil layers were noted in the unit which was excavated to a depth of $80 \mathrm{~cm}$. The upper soil zone consisted of uncompacted, fine-grained topsoil. This soil graduated into a more compacted, less organic zone between 20 to $30 \mathrm{~cm}$ below the surface. Small gravel and pebble intrusions occurred at ca. $30 \mathrm{~cm}$ and became a compacted pebble/gravel layer interspersed with calcareous cobbles from 40 to $80 \mathrm{~cm}$.

Lithic debris was concentrated in the upper 3 levels. A single diagnostic projectile point (Fig. 6D) was found in Level 5 (99.61 meters, ca. $50 \mathrm{~cm}$ below the surface) but was not associated with other cultural materials or features. Its presence within the upper gravel/pebble layer may indicate a disturbed primary or even secondary, redeposited, context. The dart point resembles Black and McGraw's (1985:121-123) south-central Early Expanding Stem, Group 4, Form 2. This poorly defined type is described in more detail in the Cultural Materials section of this report.

In summary, examination of hand-excavated test units at 41VV801 has identified a light scatter of lithic debris concentrated in the upper $25 \mathrm{~cm}$ of a medium-brown, fine-grained silty soil deposit. Numerous examples of random nicking and battering of these materials suggest diachronic episodes of natural turbidation. The evidence of a Late Prehistoric Perdiz arrowpoint as well as an Early Archaic dart point 
may be related to at least two identifiable occupations at this site. The presence of underlying interbedded gravels that take the place of lower soil zones also indicates extensive and violent hydrological scouring of this location. The natural impacts on Site $41 \mathrm{VV} 801$ have seriously effected the depositional integrity of cultural materials and this fact should be a consideration of both intra- and intersite interpretations. 


\section{QULTURAL MATERIALS}

Cultural materials from the prehistoric occupation at Site 41VV801 con sist of 92 fragments of 1 ithic debris recovered from subsurface contexts. This total includes 2 broken projectile points, a Perdiz arrowpoint, and a reworked Early Expanding Stem dart point. Other fragments of debitage totaling 14 specimens were surface-collected from the site area. The provenience of this material and identified individual characteristics are presented in Table 3. The reader is referred to Crabtree (1972) and Black and McGraw (1985:66-75) for a more detailed discussion of the characteristics and definition of unmodified and modified lithic debris. The 2 diagnostic projectile points are discussed below and are illustrated, as are other selected artifacts referred to in Table 3 , in Figure 6.

\section{Specimen 1}

The Perdiz arrowpoint (Fig. 6B) was recovered from Test Unit 3 at 99.75 meters elevation. It measures $4.57 \mathrm{~cm}$ long, $2.00 \mathrm{~cm}$ wide, and $0.35 \mathrm{~cm}$ thick. Stem length is $1.43 \mathrm{~cm}$. Weight is $2.5 \mathrm{gr}$.

This specimen lacks ca.5 mm of one of the blade's barbs. Blade edges are slightly convex and one blade face is only marginally retouched. The stem is contracting and stem length is approximately $1 / 3$ of the total length. This arrowpoint is similar to those described by Suhm and Jelks (1962:283) and Turner and Hester (1985:187) as the Late prehistoric Perdiz type (A.D. 1200 to 1500). The specimen falls within the upper range of measurements for this type and appears similar to other 
specimens recovered from 41KM16, the Buckhollow Site, in nearby Kimble County, ca. 112 kilometers (70 miles) northeast of 41VV801 (Denton n.d.). It should be noted that six radiocarbon assays thought to be associated with this Perdiz variant from 41KM16 range from A.D. 1600+/-60 to A.D. 1840+/-50. Five of the assays range between A.D. 1600 to A.D. 1760, with a maximum range spread of $+/-70$ years. These dates, of course, strongly suggest a Historical Indian context for this type.

Specimen 2

Specimen 2 is an Early Expanding Stem dart point (Fig. 6D). Its provenience is Test Unit 4, 99.66 meters. Measurements are: length, 5.43 $\mathrm{cm}$; width, $2.38 \mathrm{~cm}$; thickness, $0.72 \mathrm{~cm}$. Weight is $10.5 \mathrm{gr}$.

Completely patinated, this specimen consists of a narrow, triangularbladed dart point with an alternately beveled distal end. Reworking in the form of abrasion of the blade edges below the beveling has altered the angle and extent of the original blade edges. The stem is slightly expanding and the basal concavity is quite shallow. The original extent of corner notching has been effected by lower blade edge abrasion. The edges of the shallow basal concavity are the only portions of the specimen that have not been dulled.

The reworking of this artifact, especially the extent of blade and stem abrasion, suggests a purposeful dulling along most of the specimen's length, perhaps for hafting. It is possible that such binding would be necessary, for example, to compensate for the severe twisting, 
shear-stress movement generated during use as a perforator of hard materials. The artifact's utilization as a perforator is reflected by the alternate beveling of its distal end.

Morphologically, this specimen is similar in general characteristics to Weir's (1976:Fig. 9d) and Turner and Hester's (1985:155) Uvalde type. Black and McGraw (1985:123), however, have pointed out that this type is poorly defined. Given the type's early chronological context, this report will follow the format of Black and McGraw (1985) and identify it as an unnamed variant of Early Expanding Stem, Early Archaic dart point (Group 4, Form 2) (see also Black and McGraw 1985:121-123; Weir 1976; Suhm and Jelks 1962:255; and Hester 1980:98,146-149, for a further discussion of this type and its chronological context). 
Site 41VV801 represents the disturbed remains of a small, open campsite occupied during at least two widely separated cultural periods of the prehistoric past. The remains of these early activities have been severely affected by hydraulic scouring of the low terrace above Red Bluff Creek. Random nicking and abrasion of much of the recovered lithic debitage suggests that some buried materials are in a secondary, or redeposited, context. The upper soil zone of Site 41VV801, to a depth of 25-30 cm, contains elements of at least one Late Prehistoric Perdizassociated occupation. The paucity of lithic materials and features, however, suggests that the main site area is beyond the modern highway right-of-way or has been destroyed previously by earlier highway/bridge construction.

A review of Figure 7 and the material proveniences of Table 3 indicates an upper deposit of cultural materials that noticeably increases upslope and perhaps beyond the areas of Test Units 3 and 4 . Levels 2 and 3 of Unit 3 and Levels 1 through 3 of Unit 4 contain almost $48 \%$ of the total recovered subsurface lithic debris from the site. This recovery is contrasted to the ephemeral traces of a lower cultural deposit noted in the lower levels of all tested units. A composite profile illustrating the material distributions and intrasite stratigraphic relation ships is presented in Figure 7.

The two chronologically diagnostic artifacts, a large Perdiz arrowpoint and an Early Archaic dart point recovered from testing, reflect a long span of sporadic site occupation. Although Perdiz arrowpoints in other 


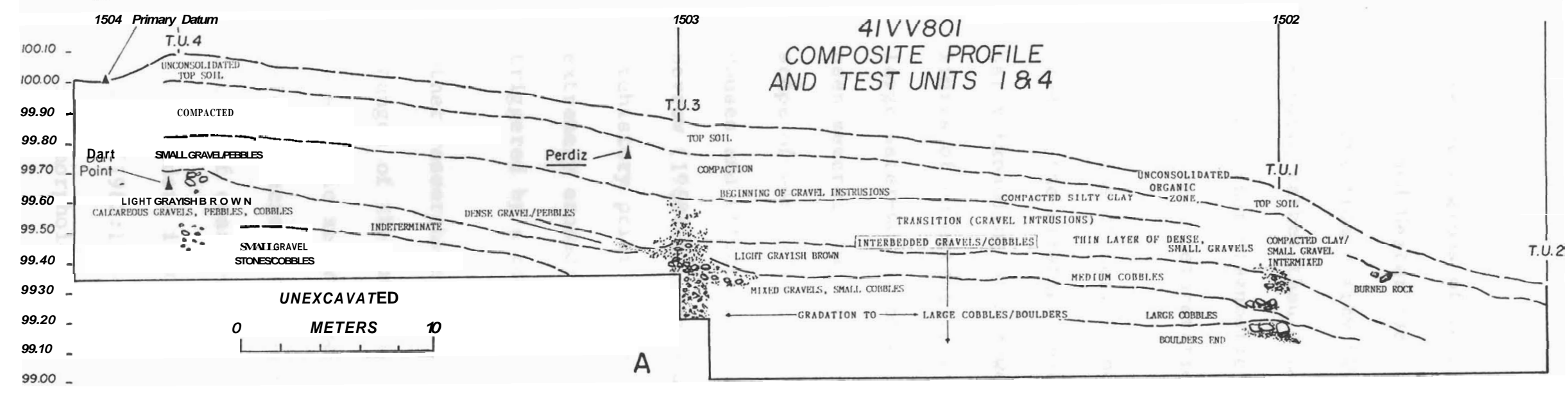

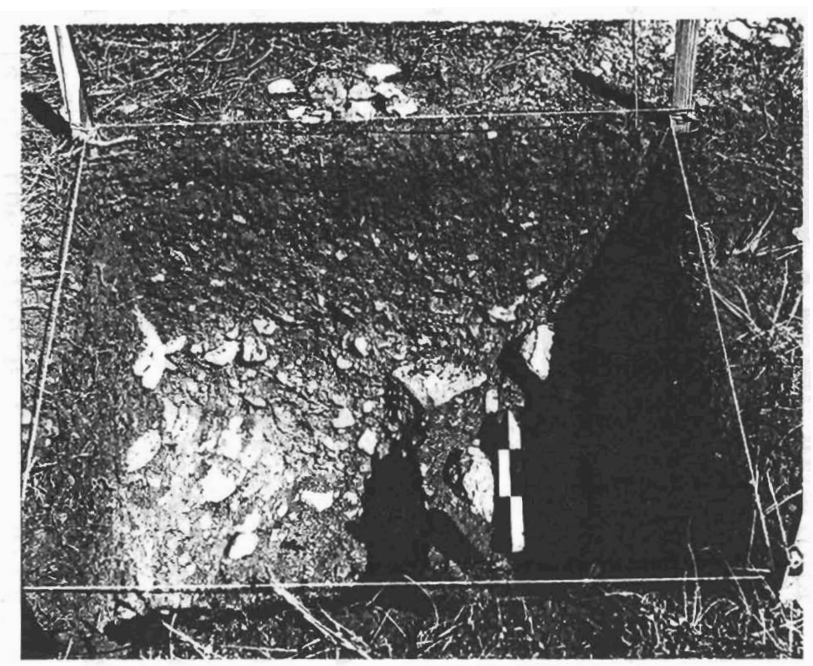

B

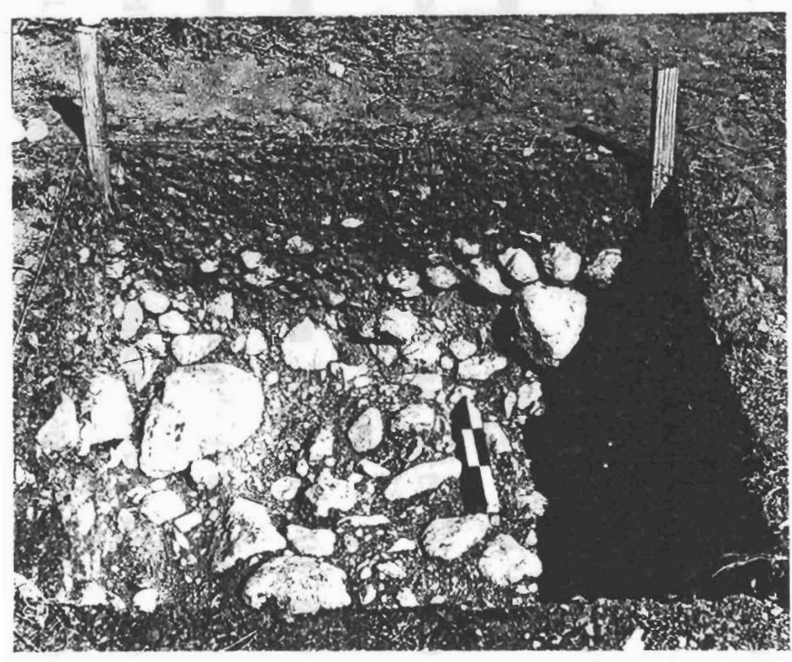

C

FIGURE 7. Composite stratigraphic profile at $41 \mathrm{~V} \vee 801$. A. D eposits along east walls, Test Units 1-4; B, gravel/pebble matrix along north wall and floor of Test Unit 4; C, calcareous cobbles and interbedded gravels in floor of Test Unit 1. 
adjacent regions of Texas range in age from ca. AD 1200 to AD 1500 (Turner and Hester 1985:187), the radiocarbon assays associated with specimens from nearby 41KM16 in Kimble County (Denton n.d.) suggest an Historic rather than a Late Prehistoric context. Unfortunately, the lack of other diagnostic materials or features preclude any further substantive interpretations of this time span at Site $41 \mathrm{VV} 801$.

The remains of earlier occupational sequences at $41 \mathrm{~W} 801$ are characterized by the stratigraphic position of the second diagnostic specimen, an Early Expanding Stem reworked dart point. Recovered from the upper limits of an extensive gravel/pebble deposit and overlying deposits of large water-worn cobbles, it is representative of materials that have been severely impacted by natural erosional processes. The limited scope of work at Site 41VV801 precludes a detailed discussion of the causes and effects of episodic flooding in this area of the Lower Pecos. Sorrow (1968:65), for example, discusses a major erosional period of prehistory prior to 4000 B.P. in which the edges of river terraces were extremely eroded; he suggests that this erosional episode may have been triggered by a continuing trend toward increasing aridity.

Other researchers (Patton and Dibble 1982:119) have pointed out that changes of the area's hydrology, especially sediment load, are related to specific xeric or mesic conditions. They suggest that periods of aridity decrease the vegetation along slopes and promote the transportation of coarse-grained sediments, perhaps like the large cobbles and boulders in the lower levels of the site's test units. Patton and Dibble (1982:117) also point out that the degree of sinuosity (of stream morphology) may be related to the frequency and magnitude 
of stream flow during flooding episodes. Periods of channel/terrace evolutions may be characterized by buried soil depositions related to humid/wet climatic phases as contrasted to flood gravel deposits of arid phases.

In conclusion, future researchers of site patterns and distributions should recognize the significance of Site 4lVV801 and its reflection of site destruction by episodic flooding sequences. That certain elements of such site patterns have become almost unidentifiable should be a careful consideration in the formulation of a regional chronological sequence and inferences toward changing patterns of resource exploitations. 


\section{RECOMMENDATIONS}

Following intensive survey, limited testing, and material analyses, Site 41VV801 is considered to represent the remains of a prehistoric temporary campsite location that was sporadically occupied during the Late Prehistoric (possibly Historic) and Early Archaic time frames.

Given the extent of natural impacts and the severity of site destruc tion due to hydrological scouring, as well as the paucity of cultural remains, no further work is recommended. For the same reasons, it is felt that Site 41VV801 does not warrant designation as a State Archeo logical Landmark. 
Bement, Leland C.

1986 Excavation of the Late Pleistocene Deposits of Bonfire Shelter. Val Verde County, Texas. Archeology Series 1. Texas Archeological Survey, The University of Texas a t Austin.

Black, Stephen L., and A. Joachim McGraw 1985

The Panther Springs Creek Site: Cultural Change and Continuity Within The Upper Salado Creek Watershed, South-Central Texas. Archaeological Survey Report 100. Center for Archaeological Research, The University of Texas at San Antonio.

Blair, Frank W.

1950 The Biotic Provinces of Texas. The Texas Journal of Science 2:93-117.

Bryant, Vaughn M., Jr. 1966 Pollen Analysis: Its Environmental and Cultural Implications in the Amistad Reservoir Area. Master's thesis, Department of Anthropology, The University of Texas at Austin.

Collins, Michael B.

1974 A Functional Analysis of Lithic Technology Among Pre historic Hunters and Gatherers of Southwestern France and Western Texas. Ph.D. dissertation, Department of Anthropology, The University of Arizona. Tucson.

Council of Texas Archeologists

1985 Guidelines for Performance, Curation, and Reports.

Council of Texas Archeologists.

Crabtree, Don E.

1972 An Introduction to Flintworking. Occasional Papers of the Idaho State University Museum 28.

Davis, William B.

1960 The Mammals of Texas. Bulletin of the Texas Game and Fish Commission 27:1-52.

Denton, Joe T.

n.d. Excavations at the Buckhollow Site, A Multicomponent Prehistoric Site in Kimble County, Texas. Manuscript on file, Archaeology Section, Highway Design Division, Texas State Department of Highways and Public Trans portation. Austin. 
Dering, James P.

1979

Pollen and Plant Macrofossil Vegetation Record Recovered from Hinds Cave. Val Verde Countv. Texas. A nthropology

Research Laboratory, Texas A\&M University. College

Station.

Dibble, David S.

n.d. Arenosa Shelter: The Descriptive Archeology. Report in preparation to the National Park Service.

Dibble, David S., and Dessamae Lorrain

1968 Bonfire Shelter: A Stratified Bison Kill Site, Val Verde

County, Texas. Memorial Museum Miscellaneous Papers. The

University of Texas at Austin.

Golden, Michael L., Wayne J. Gabriel, and Jack W. Stevens

1982 Soil Survey of Val Verde County, Texas. U.S. Department

of Agriculture, Soil Conservation Service.

Hester, Thomas $\mathbf{K}$.

$1980 \quad$ Digging Into South Texas Prehistory. Corona Press.

San Antonio.

Johnson, Elmer H.

1931 The Natural Regions of Texas. Bureau of Business

Research Monograph 8, University of Texas Bulletin

3113. The University of Texas at Austin.

Lundelius, Ernest L., Jr.

1984 A Late Pleistocene Mammalian Fauna from Cueva Quebrada,

Val Verde County, Texas. Contributions in Quaternary

Vertebrate Paleontology, edited by H. H. Genoways and M.

R. Dawson. Special Publications 8:456-481. Carnegie

Museum of Natural History.

Patton, Peter C.

1977 Geomorphic Criteria for Estimating the Magnitude and

Frequency of Flooding in Central Texas. Ph.D. dissertation, The University of Texas at Austin.

Patton, Peter C., and David S. Dibble

1982 Archeologic and Geomorphic Evidence for the Paleo-

Hydrologic Record of the Pecos River in West Texas.

American Journal of Science 282:97-121. 
Sorrow, William M.

1968 The Devil's Mouth Site: The Third Season - 1967, Papers of the Texas Archeological Salvage Project 14.

Austin.

Story, Dee Ann, and Vaughn Bryant, Jr. (Editors)

1966 A Preliminary Study of the Paleo-Ecology of the Amistad Reservoir Area. Report to the National Science Foundation (GS 667) by The University of Texas at Austin.

Suhm, Dee Ann, and Edward B. Jelks

1962 Handbook of Texas Archeology: Type Descriptions. Texas Archeological Society Special Publications 1 and $\overline{\text { Texas }}$ Memorial Museum Bulletin 4. Austin.

Turner, Ellen S., and Thomas R. Hester

1985 A Field Guide To Stone Artifacts. Texas Monthly Press.

Austin.

Turpin, Solveig A.

1984 Prehistory in the Lower Pecos River Region: An Overview.

Research Report 90. Texas Archeological Survey, The University of Texas at Austin.

1985 Seminole Sink: Excavation of a Vertical Shaft Tomb. Research Report 93. Texas Archeological Survey, The University of Texas at Austin.

Weir, Frank A. 1976

The Central Texas Archaic. Ph.D. dissertation, Department of Anthropology, Washington State University, Pullman. University Microfilms, Ann Arbor. 